\title{
Potential use of a diluted high-relaxivity gadolinium-based intra-articular contrast agent for magnetic resonance arthrography: an in-vitro study
}

Carmelo Messina ${ }^{1,2}$, Domenico Albano ${ }^{1,3^{*}}$ (D) , Davide Orlandi ${ }^{4}$, Vito Chianca ${ }^{1}$, Angelo Corazza ${ }^{1}$, Federica Ferrari ${ }^{5}$, Salvatore Gitto ${ }^{5}$ and Luca Maria Sconfienza ${ }^{1,2}$

\begin{abstract}
Background: Magnetic resonance arthrography (MRA) requires intra-articular injection of gadolinium-based diluted paramagnetic contrast material. To our knowledge, gadobenate dimeglumine (Gd-BOPTA) has never been used for intra-articular applications. Our aim was to test in vitro different concentrations of Gd-BOPTA to be potentially used to perform MRA.

Methods: Gd-BOPTA was diluted in saline ( $\mathrm{NaCl} 0.9 \%)$ to achieve different concentrations ( $4 \mathrm{mmol} / / ; 2 \mathrm{mmol} / / ; 1 \mathrm{mmol} / /$; $0.67 \mathrm{mmo} / / / ; 0.5 \mathrm{mmo} / / \mathrm{l})$. Six sets of five sterile pipes were prepared with $5 \mathrm{ml}$ of each solution, five sets added with $0.5 \mathrm{ml}$ of fresh synovial fluid. Two separate pipes were prepared with $5 \mathrm{ml}$ of gadopentetate dimeglumine (Gd-DTPA) at 2 $\mathrm{mmol} / \mathrm{l}$, one pipe added with $0.5 \mathrm{ml}$ of synovial fluid. Pipes were imaged using a T1-weighted sequence at $1.5 \mathrm{~T}$. For each pipe, signal intensity (SI) in arbitrary units (au) was measured.

Results: SI reproducibility range was 86-99\%. Mean Gd-BOPTA SI in pipes containing synovial fluid increased from $1236 \pm 8 \mathrm{au}(0.5 \mathrm{mmol} / \mathrm{l})$ up to $1610 \pm 44 \mathrm{au}(1 \mathrm{mmol} / \mathrm{l})$ and down to $1405 \pm 33 \mathrm{au}(4 \mathrm{mmol} / \mathrm{l})$. Mean Gd-BOPTA SI in pipes without synovial fluid increased from $1184 \pm 29 \mathrm{au}(0.5 \mathrm{mmol} / \mathrm{l})$ up to $1530 \pm 38 \mathrm{au}(1 \mathrm{mmol} / \mathrm{l})$, and down to $1347 \pm 39 \mathrm{au}$ ( $4 \mathrm{mmol} / \mathrm{l}$ ). Sl of pipes without synovial fluid was lower than that of pipes with synovial fluid for both Gd-BOPTA and GdDTPA ( $P \leq 0.002)$. Regarding pipes with synovial fluid, mean Gd-DTPA SI at $2 \mathrm{mmol} / \mathrm{I}$ was $1246 \pm 27 \mathrm{au}$. Compared with Gd-BOPTA, SI was not different at $0.5 \mathrm{mmol} / \mathrm{I}(-0.2 \%, P=0.587)$ while it was higher $(P<0.001)$ at all other concentrations (range $+13.3 \%[4 \mathrm{mmol} / \mathrm{l}]-+28.3 \%[1 \mathrm{mmol} / \mathrm{l}])$. Regarding pipes without synovial fluid, mean Gd-DTPA SI at $2 \mathrm{mmol} / \mathrm{l}$ was $1275 \pm 56 a u$. Compared with Gd-BOPTA, SI was lower at $0.5 \mathrm{mmol} / \mathrm{l}(-6.8 \%, P<0.001)$, while it was higher $(P<0.001)$ at all other concentrations (range $+6.1 \%[4 \mathrm{mmol} / \mathrm{l}]-+19.6 \%[1 \mathrm{mmol} / \mathrm{l}])$.
\end{abstract}

Conclusions: In vitro, Gd-BOPTA at $1 \mathrm{mmol} / \mathrm{had}$ a $+28 \% \mathrm{SI}$ increase in comparison to Gd-DTPA $2 \mathrm{mmol} / \mathrm{l}$. SI similar to Gd-DTPA can be obtained using one fourth concentration of Gd-BOPTA.

Keywords: Magnetic resonance arthrography, Gadobenate dimeglumine, Gadopentetate dimeglumine, In vitro study

\footnotetext{
*Correspondence: albanodomenico@me.com

'IRCCS Istituto Ortopedico Galeazzi, Via R. Galeazzi 4, 20161 Milan, Italy

${ }^{3}$ Sezione di Scienze Radiologiche, Dipartimento di Biomedicina, Neuroscienze e Diagnostica Avanzata, Università degli Studi di Palermo, Via del Vespro 127, 90127 Palermo, Italy

Full list of author information is available at the end of the article
}

(c) The Author(s). 2019 Open Access This article is distributed under the terms of the Creative Commons Attribution 4.0 International License (http://creativecommons.org/licenses/by/4.0/), which permits unrestricted use, distribution, and reproduction in any medium, provided you give appropriate credit to the original author(s) and the source, provide a link to the Creative Commons license, and indicate if changes were made. The Creative Commons Public Domain Dedication waiver (http://creativecommons.org/publicdomain/zero/1.0/) applies to the data made available in this article, unless otherwise stated. 


\section{Background}

Magnetic resonance imaging (MRI) has become the most important diagnostic tool for the assessment of joint disorders throughout the body, allowing for detecting abnormalities of the joint space, cartilage, fibrocartilages, tendons, ligaments, and synovial tissue [1]. In this setting, a further advanced tool is represented by MR arthrography (MRA), which is mainly used to evaluate young and less young patients and has been demonstrated to be superior in detecting a number of intraarticular joint abnormalities compared to conventional MRI $[2,3]$.

MRA requires intra-articular injection of gadolinium-based diluted paramagnetic contrast material $[1,4]$. Contrast solution is injected until the capsule distends [5]. Traditionally, paramagnetic contrast solution was prepared manually, diluting a certain amount of gadolinium-based contrast agent into saline solution to obtain an approximate concentration of 2 $\mathrm{mmol} / \mathrm{l}$ [5]. A recent survey showed this approach is still used in about $60 \%$ of institutions [6]. On the other hand, two commercial preparations are available as pre-filled syringes ready to be injected. These solutions are based on gadoteric acid (Gd-DOTA, $2.5 \mathrm{mmol} / \mathrm{l}$; Dotarem, Guerbet, France) or on gadopentetate dimeglumine (Gd-DTPA, $2 \mathrm{mmol} / \mathrm{l}$; Magnevist, Bayer, Germany). These two contrast agents have different molecular structures and properties but have similar R1-relaxivity values of approximately $4.2-5.31 / \mathrm{mmols}^{-1}$ at $1.5 \mathrm{~T}$ and produce similar contrast enhancement when administered at the same dose [7]. Gadobenate dimeglumine (Gd-BOPTA, MultiHance, Bracco Imaging SpA, Italy) is a gadolinium-based contrast agent which has unique features compared to other agents, including very high R1-relaxivity thanks to a transient weak binding to blood proteins and is mostly used for liver imaging [8].

To our knowledge, Gd-BOPTA has never been used for intra-articular applications.

The purpose of our study was to test in vitro different concentrations of Gd-BOPTA to be potentially used for MRA.

\section{Methods}

Preparation of pipes

Six sets of six sterile pipes were prepared at different concentrations, 36 pipes overall (Fig. 1a). For all sets, Gd-BOPTA and saline solution $(\mathrm{NaCl} 0.9 \%)$ were mixed into five pipes in order to achieve a concentration of 4 $\mathrm{mmol} / \mathrm{l}, 2 \mathrm{mmol} / \mathrm{l}, 1 \mathrm{mmol} / \mathrm{l}, 0.67 \mathrm{mmol} / \mathrm{l}$, and $0.5 \mathrm{mmol} /$ l; the sixth pipe was filled with $5 \mathrm{ml}$ of $2 \mathrm{mmol} / \mathrm{l}$ prediluted Gd-DTPA and served as a reference (Fig. 1b). We used Gd-DTPA as reference standard since it is one of the most commonly used contrast agents in prediluted syringes for MRA examinations and it is also that used at our Institution.

To simulate the environment of a joint, five sets of pipes prepared as reported above were added with $0.5 \mathrm{ml}$ of fresh synovial fluid withdrawn from the knees of five patients presenting to our department for intra-articular injections (three males, two females; mean age $68 \pm 8$ years) (Fig. 1c). These patients were

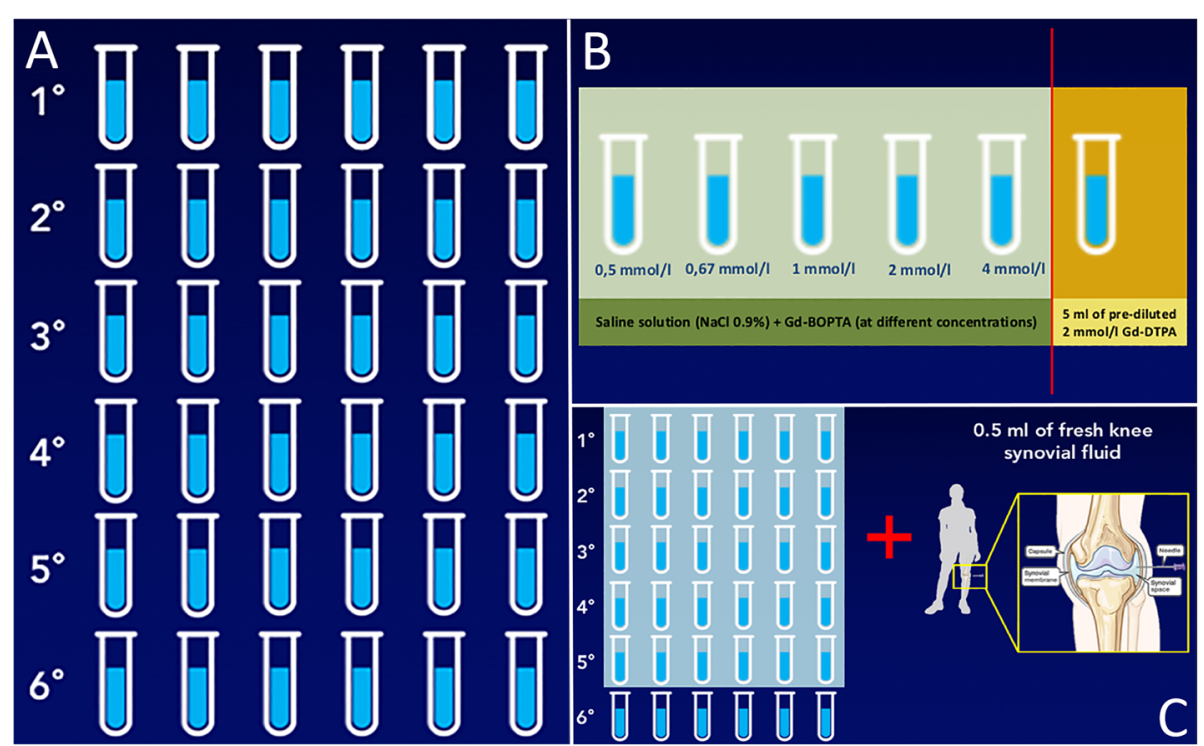

Fig. 1 Six sets of six sterile pipes were prepared at different concentrations, 36 pipes overall (a). For all sets, Gd-BOPTA and saline solution (NaCl $0.9 \%$ ) were mixed into five pipes in order to achieve a concentration of $4 \mathrm{mmol} / \mathrm{l}, 2 \mathrm{mmol} / \mathrm{l}, 1 \mathrm{mmol} / \mathrm{l}, 0.67 \mathrm{mmol} / \mathrm{l}$, and $0.5 \mathrm{mmol} / \mathrm{l}$; the sixth pipe was filled with $5 \mathrm{ml}$ of $2 \mathrm{mmol} / \mathrm{l}$ pre-diluted Gd-DTPA and served as a reference (b). To simulate the environment of a joint, five sets of pipes were added with $0.5 \mathrm{ml}$ of fresh synovial fluid withdrawn from the knees of five patients presenting to our department for intra-articular injections (c) 
all affected by degenerative osteoarthritis grade II according to Kellgren-Lawrence [9].

\section{Imaging protocol and statistical analysis}

All six sets of pipes were imaged independently using an axial T1-weighted sequence $(\mathrm{TE}=9.8 \mathrm{~ms}, \mathrm{TR}=678 \mathrm{~ms}$, slice thickness $3.5 \mathrm{~mm}$, FOV $320 \times 320 \mathrm{~mm}$ ) at $1.5 \mathrm{~T}$ (Sonata Maestro Class, Siemens Medical Solution, Erlangen, Germany) using a 4-channel phased-array surface coil. The same sequence was repeated twice to test reproducibility. Fourteen slices per pipe were obtained.

For each image, signal intensity (SI) in arbitrary units (au) was measured by one observer using a 4-mm diameter region of interest (Horos 3.3.5, www.horosproject. info) placed approximately in the middle of the image. For each pipe, the mean and standard deviation (SD) of SI over the 14 regions of interest was calculated. To compare the SI of Gd-BOPTA and Gd-DTPA, data from all the pipes and all the measurements were averaged.

Reproducibility between SI of each pipe was tested using the Bland-Altman method. Differences of SI between pipes at the same concentration of the two sets (with or without synovial fluid) and between pipes containing GdBOPTA at different concentrations and Gd-DTPA were assessed using the Mann-Whitney $U$ test. Differences of SI among the five sets of pipes containing Gd-BOPTA per each concentration were tested using the Kruskal-Wallis test. The SPSS program (v.24, IBM, NY) was used. $P$-value threshold was set at 0.003 for multiple comparison correction.

\section{Results}

Figure 2 shows T1-weighted axial scan of the two different sets of pipes containing different solutions of

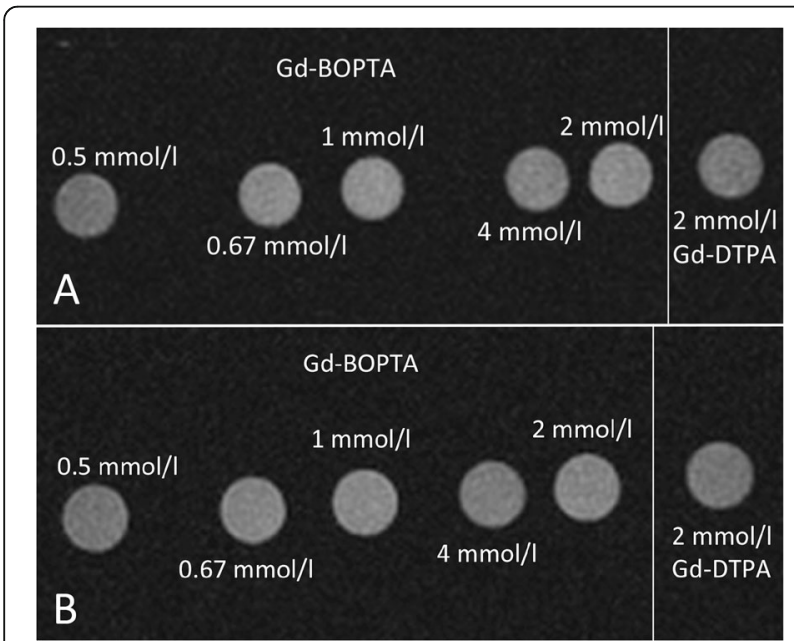

Fig. 2 T1-weighted axial scan of two different sets of pipes containing different solutions of gadolinium-based contrast (a) with or (b) without addition of synovial fluid gadolinium-based contrast with and without addition of synovial fluid.

\section{Reproducibility}

The reproducibility of SI measurement on the same pipe ranged from $86 \%$ (Gd-BOPTA $0.67 \mathrm{mmol} / \mathrm{l}$ without synovial fluid) to $99 \%$ (Gd-BOPTA $0.5 \mathrm{mmol} / \mathrm{l}$, set \#2 and set \#3). Full data is reported in Table 1.

\section{SI of Gd-BOPTA pipes}

The mean SI of Gd-BOPTA in pipes containing synovial fluid increased from $1236 \pm 8$ au at $0.50 \mathrm{mmol} / \mathrm{l}$ (set \#4, scan \#1) up to $1610 \pm 44$ au at $1.00 \mathrm{mmol} / \mathrm{l}$ (set \#4, scan \#1) and down to $1405 \pm 33$ au at $4.00 \mathrm{mmol} / \mathrm{l}$ (set \#5, scan \#2). SI within pipe sets was homogeneous, with no significant differences among them $(P>0.004)$.

The mean SI of Gd-BOPTA in pipes not containing synovial fluid showed an increase from $1184 \pm 29$ au at $0.50 \mathrm{mmol} / \mathrm{l}$ (set \#6, scan \#1) up to $1530 \pm 38$ au at 1.00 $\mathrm{mmol} / \mathrm{l}$ (set \#6, scan \#1), and down to $1347 \pm 39$ au at $4.00 \mathrm{mmol} / \mathrm{l}$ (set \#6, scan \#1).

SI of pipes without synovial fluid was significantly lower than that of pipes with synovial fluid for both GdBOPTA and Gd-DTPA $(P \leq 0.002)$.

Full data is reported in Table 1 and graphically represented in Fig. 3.

\section{Comparison between Gd-BOPTA and Gd-DTPA}

Regarding pipes with synovial fluid, the mean SI of GdDTPA at $2 \mathrm{mmol} / \mathrm{l}$ was $1246 \pm 27$ au. In comparison with Gd-BOPTA, SI was not significantly different at $0.5 \mathrm{mmol} / \mathrm{l}(-0.2 \%, P=0.587)$ while it was significantly higher at all other concentrations (range $+13.3 \%$ at 4 $\mathrm{mmol} / \mathrm{l}$ to $28.3 \%$ at $1 \mathrm{mmol} / \mathrm{l}, P<0.001$ ).

Regarding pipes without synovial fluid, the mean SI of Gd-DTPA at $2 \mathrm{mmol} / \mathrm{l}$ was $1275 \pm 56$ au. In comparison with Gd-BOPTA, SI was significantly lower at $0.5 \mathrm{mmol} / \mathrm{l}(-6.8 \%, \mathrm{P}<0.001)$ while it was significantly higher at all other concentrations (range $+6.1 \%$ at $4 \mathrm{mmol} / \mathrm{l}$ to $19.6 \%$ at $1 \mathrm{mmol} / \mathrm{l}, \mathrm{P}<0.001)$. Full data is reported in Table 2.

\section{Discussion}

Our in vitro experience demonstrated that synovial fluid slightly but significantly increased SI of Gd-BOPTA. In pipes containing synovial fluid, Gd-BOPTA at $1 \mathrm{mmol} / \mathrm{l}$ had a $+28 \%$ SI increase in comparison to Gd-DTPA 2 $\mathrm{mmol} / \mathrm{l}$.

Gd-BOPTA has unique features that distinguish it from all other gadolinium-based contrast media. In particular, it has a dual route of elimination from the body that enables Gd-BOPTA to be used both as nonspecific agent and liverspecific agent [10]. Moreover, a higher R1-relaxivity compared to other gadolinum-based contrast agents permits 
Table 1 Comparison of signal intensities of different solution concentrations of gadolinium-based contrast agents with or without addition of synovial fluid and their reproducibility

\begin{tabular}{|c|c|c|c|c|c|c|c|c|c|}
\hline & & & $\begin{array}{l}\text { Gd-BOPTA } 0.5 \\
\mathrm{mmol} / \mathrm{l}\end{array}$ & $\begin{array}{l}\text { Gd-BOPTA } 0.67 \\
\mathrm{mmol} / /\end{array}$ & $\begin{array}{l}\text { Gd-BOPTA } 1 \\
\mathrm{mmol} / \mathrm{l}\end{array}$ & $\begin{array}{l}\text { Gd-BOPTA } 2 \\
\mathrm{mmol} / \mathrm{l}\end{array}$ & $\begin{array}{l}\text { Gd-BOPTA } 4 \\
\mathrm{mmol} / \mathrm{l}\end{array}$ & $\begin{array}{l}\text { Gd-DTPA } 2 \\
\mathrm{mmol} / /\end{array}$ & Saline \\
\hline \multirow[t]{16}{*}{$\begin{array}{l}0.5 \mathrm{ml} \text { of } \\
\text { synovial fluid }\end{array}$} & $\begin{array}{l}\text { Set } \\
\# 1\end{array}$ & Scan \#1 & $1241 \pm 19$ & $1481 \pm 50$ & $1583 \pm 34$ & $1521 \pm 29$ & $1414 \pm 34$ & $1204 \pm 59$ & $\begin{array}{l}403 \pm \\
6\end{array}$ \\
\hline & & Scan \#2 & $1247 \pm 13$ & $1464 \pm 60$ & $1577 \pm 35$ & $1514 \pm 26$ & $1416 \pm 37$ & $1234 \pm 47$ & $\begin{array}{l}403 \pm \\
6\end{array}$ \\
\hline & & $\begin{array}{l}\text { Coefficient of } \\
\text { repeatability }\end{array}$ & $97 \%$ & $90 \%$ & $95 \%$ & $95 \%$ & $94 \%$ & $89 \%$ & $96 \%$ \\
\hline & $\begin{array}{l}\text { Set } \\
\# 2\end{array}$ & Scan \#1 & $1241 \pm 8$ & $1497 \pm 49$ & $1602 \pm 52$ & $1534 \pm 39$ & $1424 \pm 37$ & $1253 \pm 50$ & $\begin{array}{l}391 \pm \\
11\end{array}$ \\
\hline & & Scan \#2 & $1241 \pm 7$ & $1461 \pm 62$ & $1604 \pm 34$ & $1542 \pm 32$ & $1419 \pm 36$ & $1238 \pm 61$ & $\begin{array}{l}398 \pm \\
16\end{array}$ \\
\hline & & $\begin{array}{l}\text { Coefficient of } \\
\text { repeatability }\end{array}$ & $99 \%$ & $90 \%$ & $93 \%$ & $94 \%$ & $93 \%$ & $87 \%$ & $91 \%$ \\
\hline & $\begin{array}{l}\text { Set } \\
\# 3\end{array}$ & Scan \#1 & $1249 \pm 13$ & $1474 \pm 45$ & $1608 \pm 37$ & $1536 \pm 35$ & $1410 \pm 32$ & $1253 \pm 37$ & $\begin{array}{l}398 \pm \\
9\end{array}$ \\
\hline & & Scan \#2 & $1244 \pm 21$ & $1442 \pm 54$ & $1596 \pm 34$ & $1527 \pm 29$ & $1415 \pm 32$ & $1234 \pm 40$ & $\begin{array}{l}400 \pm \\
7\end{array}$ \\
\hline & & $\begin{array}{l}\text { Coefficient of } \\
\text { repeatability }\end{array}$ & $99 \%$ & $90 \%$ & $93 \%$ & $94 \%$ & $93 \%$ & $87 \%$ & $91 \%$ \\
\hline & $\begin{array}{l}\text { Set } \\
\# 4\end{array}$ & Scan \#1 & $1236 \pm 8$ & $1486 \pm 61$ & $1610 \pm 44$ & $1524 \pm 32$ & $1406 \pm 38$ & $1232 \pm 46$ & $\begin{array}{l}409 \pm \\
8\end{array}$ \\
\hline & & Scan \#2 & $1243 \pm 17$ & $1470 \pm 46$ & $1584 \pm 37$ & $1521 \pm 32$ & $1408 \pm 28$ & $1239 \pm 53$ & $\begin{array}{l}409 \pm \\
7\end{array}$ \\
\hline & & $\begin{array}{l}\text { Coefficient of } \\
\text { repeatability }\end{array}$ & $96 \%$ & $90 \%$ & $94 \%$ & $93 \%$ & $94 \%$ & $90 \%$ & $94 \%$ \\
\hline & $\begin{array}{l}\text { Set } \\
\# 5\end{array}$ & Scan \#1 & $1246 \pm 19$ & $1496 \pm 49$ & $1601 \pm 38$ & $1540 \pm 26$ & $1411 \pm 34$ & $1266 \pm 55$ & $\begin{array}{l}404 \pm \\
6\end{array}$ \\
\hline & & Scan \#2 & $1240 \pm 14$ & $1484 \pm 44$ & $1601 \pm 27$ & $1545 \pm 27$ & $1405 \pm 33$ & $1246 \pm 46$ & $\begin{array}{l}403 \pm \\
10\end{array}$ \\
\hline & & $\begin{array}{l}\text { Coefficient of } \\
\text { repeatability }\end{array}$ & $96 \%$ & $91 \%$ & $95 \%$ & $95 \%$ & $93 \%$ & $91 \%$ & $95 \%$ \\
\hline & Differ & rences between sets & 0.714 & 0.285 & 0.213 & 0.013 & 0.411 & 0.165 & 0.000 \\
\hline \multirow[t]{3}{*}{$\begin{array}{l}\text { No synovial } \\
\text { fluid }\end{array}$} & $\begin{array}{l}\text { Set } \\
\# 6\end{array}$ & Scan \#1 & $1184 \pm 29$ & $1441 \pm 49$ & $1530 \pm 38$ & $1478 \pm 39$ & $1347 \pm 39$ & $1292 \pm 45$ & $\begin{array}{l}401 \pm \\
5\end{array}$ \\
\hline & & Scan \#2 & $1191 \pm 31$ & $1383 \pm 58$ & $1520 \pm 36$ & $1454 \pm 34$ & $1358 \pm 35$ & $1257 \pm 62$ & $\begin{array}{l}387 \pm \\
10\end{array}$ \\
\hline & & $\begin{array}{l}\text { Coefficient of } \\
\text { repeatability }\end{array}$ & $94 \%$ & $86 \%$ & $93 \%$ & $93 \%$ & $94 \%$ & $89 \%$ & $92 \%$ \\
\hline
\end{tabular}

lower overall doses to be used or provides increased SI enhancement at equivalent dose [7]. In fact, Gd-BOPTA has a weak and transient interaction with serum albumin which confers a partial blood-pool effect and a lower rate of contrast dilution compared to that of other gadolinium agents [11]. Indeed, Gd-BOPTA has been proven to be effective in brain [12], vascular [13], liver [14], and breast MRI [15], in which it can be used at lower doses compared to other gadolinium-based agents. At present, however, the use of Gd-BOPTA has been limited to the liver only, given the reported accumulation of $\mathrm{Gd}$ in patients' tissues after repeated intravenous administrations $[16,17]$. On the other hand, it should also be noted that a recent report showed how Gd does not accumulate in patients undergoing MRA [18].

Regarding MRA, the use of Gd-BOPTA has never been clearly reported before except for an animal study published in 2007 in which its effect on cartilage was tested [19]. However, in some studies dealing with MRA the type of contrast agent may be not reported [20]. Moreover, other studies used Gd-BOPTA to perform indirect MRA [21], an alternative imaging technique based on the premise that contrast material administered intravenously diffuses into the joint space, owing to high vascularization of the synovial membrane and lack of 


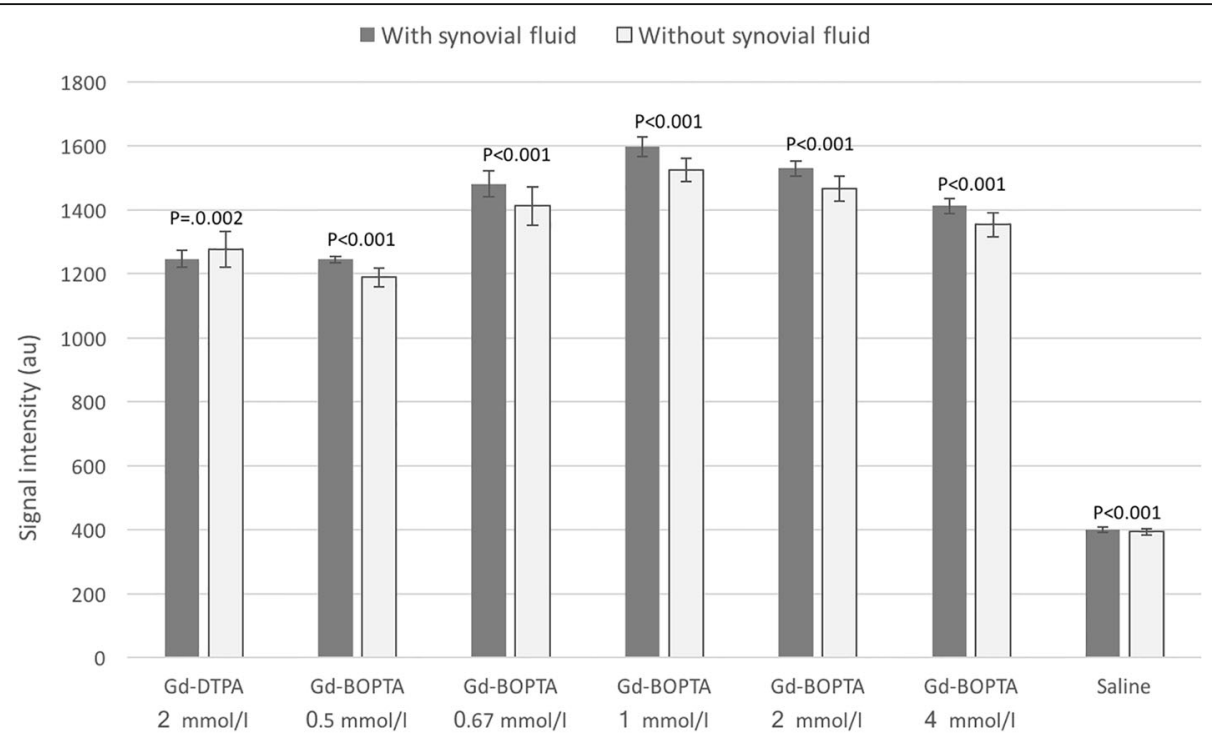

Gadolinium concentration

Fig. 3 Graphical representation of signal intensity of different solutions of gadolinium-based contrast agents with or without addition of synovial fluid and saline solution. Signal intensity of pipes without synovial fluid was significantly lower than that of pipes with synovial fluid

basement membrane in its capillaries. Compared with the direct technique, indirect MR arthrography has the main disadvantage of not allowing for capsular distension. On the other side, intravenous injection allows assessing disease activity in patients affected by inflammatory joint diseases [22]. At any rate, the use of direct MRA is continuously increasing, notwithstanding improved coils at $1.5 \mathrm{~T}$ and increased diffusion of $3 \mathrm{~T}$ systems.

Compared to $2 \mathrm{mmol} / \mathrm{l}$ solution of Gd-DTPA, SI of Gd-BOPTA was higher at all concentrations except $0.5 \mathrm{mmol} / \mathrm{l}$. The highest SI was achieved at $1 \mathrm{mmol} / \mathrm{l}$, while a similar SI was obtained at $0.5 \mathrm{mmol} / \mathrm{l}$ in pipe sets added with synovial fluid. In clinical practice, these differences may be negligible, implying that also a low concentration of gadolinium-based solution can be considered acceptable. The main practical result of these findings is that, in a simulated joint environment, the same SI of pre-diluted Gd-DTPA syringes can be obtained with up one fourth concentration of Gd-BOPTA. However, in vivo testing of this speculation should be warranted.

We acknowledge the limitations of an in vitro study in which joint environment has been reproduced only adding a small amount of synovial fluid to the contrast agent contained in sterile pipes. This implies that our data may be not directly applicable in vivo, as other factors (e.g., synovial tissue, inflammatory cytokines) may be implicated in the interaction with Gd-BOPTA. Also, body temperature may somewhat affect behavior of contrast agents in vivo, while our experiment was conducted at room temperature. Moreover, we used

Table 2 Comparison of signal intensities of different Gd-BOPTA concentrations to Gd-DTPA 2 mmol/I with or without addition of synovial fluid

\begin{tabular}{|c|c|c|c|c|c|c|c|c|}
\hline & & & $\begin{array}{l}\text { Gd-BOPTA } 0.5 \\
\mathrm{mmol} / \mathrm{l}\end{array}$ & $\begin{array}{l}\text { Gd-BOPTA } 0.67 \\
\mathrm{mmol} / \mathrm{l}\end{array}$ & $\begin{array}{l}\text { Gd-BOPTA } 1 \\
\mathrm{mmol} / \mathrm{l}\end{array}$ & $\begin{array}{l}\text { Gd-BOPTA } 2 \\
\mathrm{mmol} / \mathrm{l}\end{array}$ & $\begin{array}{l}\text { Gd-BOPTA } 4 \\
\mathrm{mmol} / \mathrm{l}\end{array}$ & Saline \\
\hline \multirow{3}{*}{$\begin{array}{l}\text { With synovial } \\
\text { fluid }\end{array}$} & \multirow{6}{*}{$\begin{array}{l}\text { Gd-DTPA } 2 \\
\mathrm{mmol} / \mathrm{l}\end{array}$} & & $1244 \pm 9$ & $1481 \pm 41$ & $1598 \pm 30$ & $1529 \pm 24$ & $1412 \pm 23$ & $401 \pm 8$ \\
\hline & & $1246 \pm 27$ & $-0.2 \%$ & $18.9 \%$ & $28.3 \%$ & $22.7 \%$ & $13.3 \%$ & $-67.8 \%$ \\
\hline & & & $P=0.587$ & $P<0.001$ & $P<0.001$ & $P<0.001$ & $P<0.001$ & $\begin{array}{l}P< \\
0.001\end{array}$ \\
\hline \multirow[t]{3}{*}{$\begin{array}{l}\text { Without } \\
\text { synovial fluid }\end{array}$} & & & $1188 \pm 29$ & $1412 \pm 60$ & $1525 \pm 36$ & $1466 \pm 38$ & $1353 \pm 37$ & $\begin{array}{l}394 \pm \\
10\end{array}$ \\
\hline & & $1275 \pm 56$ & $-6.8 \%$ & $10.7 \%$ & $19.6 \%$ & $15.0 \%$ & $6.1 \%$ & $-69.1 \%$ \\
\hline & & & $P<0.001$ & $P<0.001$ & $P<0.001$ & $P<0.001$ & $P<0.001$ & $\begin{array}{l}P< \\
0.001\end{array}$ \\
\hline
\end{tabular}


the synovial fluid withdrawn from the knees of patients with a mean age of 68 years and mild degenerative osteoarthritis. It is known that synovial fluid of elderly subjects may contain less glycoproteins and glycosaminoglycans. Thus, in younger subjects, in whom MRA is more likely to be performed, results may be somewhat different. We can speculate that a higher content of glycoproteins may further improve SI, although at present we do not have data to confirm such hypothesis. Finally, we did not assess separately $\mathrm{T} 1$ and T2 effects of the contrast media and our results are only valid for one specific parameter set TR and TE. Also, relative signal changes with noise correction should also be measured to assess reliable relaxivity values $\mathrm{R} 1$ and $\mathrm{R} 2$. However, our study was primarily aimed to measure SI, that is the most useful parameter that may affect clinical practice.

\section{Conclusions}

In conclusion, in vitro, Gd-BOPTA at $1 \mathrm{mmol} / \mathrm{had} \mathrm{a}+$ $28 \% \mathrm{SI}$ increase in comparison to Gd-DTPA $2 \mathrm{mmol} / \mathrm{l}$. A SI similar to Gd-DTPA can be obtained using one fourth concentration of Gd-BOPTA. Further in vivo studies are warranted to confirm clinical applicability and value of our results.

\section{Abbreviations}

Gd-BOPTA: Gadobenate dimeglumine; Gd-DOTA: Gadoteric acid; GdDTPA: Gadopentetate dimeglumine; MRA: Magnetic resonance arthrography; MRI: Magnetic resonance imaging

\section{Acknowledgements}

None.

\section{Authors' contributions}

Guarantor of integrity of the entire study: LMS; study concepts and design: CM, DA, DO and LMS; literature research: VC and AC; Preparation of pipes: FF and SS; Stastical analysis: SS and LMS; manuscript preparation: DA, CM and DO; manuscript editing: VC, AC and LMS. All authors have read and approved the manuscript.

\section{Funding}

This research did not receive any specific grant from funding agencies in the public, commercial, or not-for-profit sectors.

\section{Availability of data and materials}

All data are fully available upon reasonable request. The corresponding author should be contacted if someone wants to request the data.

\section{Ethics approval and consent to participate}

This study was approved by our Institutional review board (Ospedale San Raffaele, Milano, Italy) and patients' consent to participate was obtained.

\section{Consent for publication}

Written informed consent was obtained from patients.

\section{Competing interests}

Luca Maria Sconfienza and Carmelo Messina received travel support not related to the present paper by Bracco S.p.A. The other authors have no conflicts of interest to disclose.

\section{Author details}

${ }^{1}$ IRCCS Istituto Ortopedico Galeazzi, Via R. Galeazzi 4, 20161 Milan, Italy. ${ }^{2}$ Dipartimento di Scienze Biomediche per la Salute, Università degli Studi di Milano, Via Pascal 36, 20100 Milan, Italy. ${ }^{3}$ Sezione di Scienze Radiologiche, Dipartimento di Biomedicina, Neuroscienze e Diagnostica Avanzata, Università degli Studi di Palermo, Via del Vespro 127, 90127 Palermo, Italy. ${ }^{4}$ Dipartimento di Radiologia, Ospedale Evangelico Internazionale, Piazzale Gianasso 1, 16129 Genoa, Italy. ${ }^{5}$ Scuola di Specializzazione in Radiodiagnostica, Università degli Studi di Milano, Via Festa del Perdono 7, 20122 Milan, Italy.

Received: 2 August 2019 Accepted: 4 October 2019

Published online: 25 October 2019

\section{References}

1. Steinbach LS, Palmer WE, Schweitzer ME. Special focus session. MR arthrography. Radiographics. 2002;22:1223-1246.

2. Magee T, Williams D, Mani N. Shoulder MR arthrography: which patient group benefits most? AJR Am J Roentgenol. 2004;183:969-74.

3. Albano D, Chianca V, Zappia M, Russo R, Romano S, Sconfienza LM, et al. Imaging of usual and unusual complication of rotator cuff repair. J Comput Assist Tomogr. 2019;43:359-66.

4. Bellelli A, Silvestri E, Barile A, Albano D, Aliprandi A, Caudana R, et al. Position paper on magnetic resonance imaging protocols in the musculoskeletal system (excluding the spine) by the Italian College of Musculoskeletal Radiology. Radiol Med. 2019;124:522-38.

5. Helgason JW, Chandnani VP, Yu JS. MR arthrography: a review of current technique and applications. AJR Am J Roentgenol. 1997;168:1473-80.

6. Sconfienza LM, Albano D, Messina C, Silvestri E, Tagliafico AS. How, when, why in magnetic resonance arthrography: an international survey by the European Society of Musculoskeletal Radiology (ESSR). Eur Radiol. 2018;28:2356-68.

7. Pintaske J, Martirosian P, Graf H, Erb G, Lodemann KP, Claussen CD, et al. Relaxivity of Gadopentetate Dimeglumine (Magnevist), Gadobutrol (Gadovist), and Gadobenate Dimeglumine (MultiHance) in human blood plasma at 0.2, 1.5, and 3 tesla. Invest Radiol. 2006:41:213-21.Kanda T. the new restrictions on the use of linear gadolinium-based contrast agents in Japan. Magn Reson Med Sci. 2019;18:1-3.

8. Kohn MD, Sassoon AA, Fernando ND. Classifications in brief: Kellgren-Lawrence classification of osteoarthritis. Clin Orthop Relat Res. 2016:474:1886-93.

9. Cavagna FM, Maggioni F, Castelli PM, Daprà M, Imperatori LG, Lorusso V, et al. Gadolinium chelates with weak binding to serum proteins. A new class of high-efficiency, general purpose contrast agents for magnetic resonance imaging. Investig Radiol. 1997;32:780-96.

10. Johansson L, Kirchin MA, Ahlström H. Gadobenate dimeglumine (MultiHance) in MR angiography: an in-vitro phantom comparison with gadopentetate dimeglumine (Magnevist) at different concentrations. Acta Radiol. 2012;53:1112-7.

11. Rumboldt Z, Rowley HA, Steinberg F, Maldjian JA, Ruscalleda J, Gustafsson L, et al. Multicenter, double-blind, randomized, intra-individual crossover comparison of gadobenate dimeglumine and gadopentetate dimeglumine in MRI of brain tumors at 3 tesla. J Magn Reson Imaging. 2009;29:760-7.

12. Prokop M, Schneider G, Vanzulli A, Goyen M, Ruehm SG, Douek P, et al. Contrast-enhanced MR angiography of the renal arteries: blinded multicenter crossover comparison of gadobenate dimeglumine and gadopentetate dimeglumine. Radiology. 2005;234:399-408.

13. Schneider G, Maas R, Schultze Kool L, Rummeny E, Gehl HB, Lodemann KP, et al. Low-dose gadobenate dimeglumine versus standard dose gadopentetate dimeglumine for contrast-enhanced magnetic resonance imaging of the liver. Investig Radiol. 2003;38:85-94.

14. Martincich L, Faivre-Pierret M, Zechmann CM, Corcione S, van den Bosch HC, Peng WJ, et al. Multicenter, double-blind, randomized, intraindividual crossover comparison of gadobenate dimeglumine and gadopentetate dimeglumine for breast MR imaging (DETECT trial). Radiology. 2011;258:396-408.

15. Doniselli FM, Albano D, Chianca V, Cimmino MA, Sconfienza LM. Gadolinium accumulation after contrast-enhanced magnetic resonance imaging: what rheumatologists should know. Clin Rheumatol. 2017;36:977-80.

16. Savarino E, Chianca V, Bodini G, Albano D, Messina C, Tontini GE, et al. Gadolinium accumulation after contrast-enhanced magnetic resonance imaging: which implications in patients with Crohn's disease? Dig Liver Dis. 2017:49:728-30 
17. Kralik SF, Singhal KK, Frank MS, Ladd LM. Evaluation of gadolinium deposition in the brain after MR arthrography. AJR Am J Roentgenol. 2018; 211:1063-7.

18. Wiener E, Woertler K, Weirich G, Rummeny EJ, Settles M. Contrast enhanced cartilage imaging: comparison of ionic and non-ionic contrast agents. Eur J Radiol. 2007:63:110-9.

19. Fritz J, U-Thainual P, Ungi T, Flammang AJ, Fichtinger G, lordachita II, et al. Augmented reality visualization with use of image overlay technology for MR imaging guided interventions: assessment of performance in cadaveric shoulder and hip arthrography at 1.5 T. Radiology. 2012;265:254-9.

20. Nouha MR, Schweitzer ME, Ragattec RR. Contrast visibility for indirect MR arthrography with different protein contents and agent relaxivities at different field strengths: an in vitro model. Eur J Radiol. 2011;80:559-64.

21. Magarelli N, Simone F, Amelia R, Leone A, Bosello S, D'Antona G, et al. MR imaging of atlantoaxial joint in early rheumatoid arthritis. Radiol Med. 2012; 115:1111-20.

\section{Publisher's Note}

Springer Nature remains neutral with regard to jurisdictional claims in published maps and institutional affiliations.

Ready to submit your research? Choose BMC and benefit from:

- fast, convenient online submission

- thorough peer review by experienced researchers in your field

- rapid publication on acceptance

- support for research data, including large and complex data types

- gold Open Access which fosters wider collaboration and increased citations

- maximum visibility for your research: over $100 \mathrm{M}$ website views per year

At $\mathrm{BMC}$, research is always in progress.

Learn more biomedcentral.com/submissions 